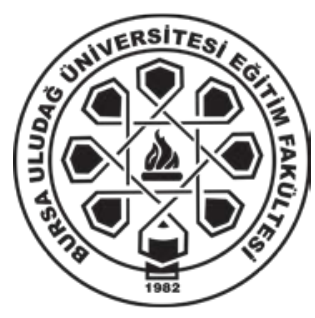

Bursa Uludağ Üniversitesi

Ĕ̆itim Fakültesi

Dergisi

Araştırma Makalesi

https://dx.doi.org/10.19171/uefad.447228

Başvuru/Received: 24.07.2018 Kabul/Accepted: 11.11..2018

\title{
Lamba Parlaklığını Etkileyen Değişkenler ile Değişkenleri Belirlemenin Öğretiminde Analoji Kullanımının Etkisi*
}

\author{
Gonca HARMAN \\ Dr. Öğr. Üyesi, Karamanoğlu Mehmetbey Üniversitesi, \\ drgoncaharman@hotmail.com, OrcID: 0000-0002-9717-1150 \\ Aytekin ÇÖKELEZ \\ Prof. Dr., İstanbul Teknik Üniversitesi, \\ cokelez@itu.edu.tr,OrcID: 0000-0002-8742-3246
}

\section{ÖZET}

$\mathrm{Bu}$ araştırmada lamba parlaklığını etkileyen değişkenler ile değişkenleri belirlemenin öğretiminde analoji kullanımının öğrenme ve kavram yanılgılarının giderilmesi üzerindeki etkisi incelenmiştir. Araştırmaya ortaokul beşinci sınıfta öğrenim görmekte olan 98 öğrenci katılmıştır. Araştırmada yarı deneysel desen çeşitlerinden eşitlenmemiş kontrol gruplu ön ve son test desen kullanılmış, yarı yapılandırılmış görüşmeler yapılmıştır. Uygulama sürecinde deney grubunda analoji, kontrol grubunda ise analoji kullanılmadan ders işlenmiştir. Araştırmada 9 sorudan oluşan bir veri toplama aracı kullanılmıştır. Elde edilen veriler içerik analizi ile

$\mathrm{Bu}$ çalışma Gonca Harman'ın doktora tezinden üretilmiş olup Ondokuz Mayıs Üniversitesi tarafindan PYO.EGF.1904.13.006 kodlu proje ile desteklenmiştir.

Sorumlu Yazar: Dr. Gonca HARMAN, drgoncaharman@hotmail.com 
çözümlenmiştir. Araştırma sonucunda analoji kullanımının öğrenme ve kavram yanılgılarının giderilmesi üzerinde etkili olduğu saptanmıştır.

Anahtar Sözcükler: Analoji, Değişkenleri Belirleme, Lamba Parlaklığını Etkileyen Değişkenler, Beşinci Sınıf Öğrencisi.

\title{
The Effect of Using Analogy on the Teaching of Variables Affecting on the Brightness of a Bulb with Identifying Variables
}

\begin{abstract}
This study was investigated the effect of using analogy on the teaching of variables affecting on the brightness of a bulb, identifying variables, learning and elimination misconceptions. The study was conducted with the participation of 98 fifth grade students attending the middle school. The unmatched control group pretest and posttest method was used in this study, interviews were done with the students. Analogy was used in the experimental group and analogy was not used in the control group in the implementation process. A data collection form consisting of 9 questions was used in this study. Data were analyzed using content analysis. As a result of this research, it was determined that the using of analogy was effective on the learning and elimination of misconceptions.
\end{abstract}

Key Words: Analogy, Identifying Variables, Variables Affecting on the Brightness of a Bulb, Fifth Grade Student.

\section{GİRIŞ}

Bilimsel süreç becerileri öğrencileri öğrenme ortamında aktifleştiren, öğrenme sorumluluğu ve araştırma yeteneği kazandıran, kolay ve kalıcı öğrenmeyi sağlayan becerilerdir (Akdeniz, 2011). Bilimsel süreç becerileri bilim insanlarının bilgi üretirken kullandıkları yöntemlerin fen öğretimine yansımasıdır. Son derece önemli olan bu beceriler bilimsel okuryazar toplumlarda çeşitli meslek gruplarındaki bireylerin sahip olması ve kullanması gereken, hayatın hemen her alanına uygulanabilen süreçleri kapsamaktadır. Bilimsel süreç becerilerini kullanmak günlük hayatta karşılaşılan olayları anlamayı, yorumlamayı ve öğrenilen bilgilerle ilişki kurmayı, bilimsel okuryazar bir birey olmayı sağlamaktadır. Öğrencilerin laboratuvarda, derslerde ve günlük hayatta olaylara bilim insanı gibi bakan, araştıran, sorgulayan, yaratıcı düşünceler üreten bireyler olmaları açısından bu becerilerin geliştirilmesi gereklidir (Temiz ve Tan, 2009). Öğrencilerin bilimsel süreç becerilerini edinmeleri ve geliştirmeleri bağlamında erken 
yaşlarda deneyim kazanmaları son derece önemlidir (Durmaz ve Mutlu, 2012). Bu nedenle bilimsel süreç becerilerinin bireylere kazandırılması için okul öncesinden başlanarak konunun öğretimine yer verilmelidir. Bunun yanında fen derslerinde kullanılan ölçme değerlendirme etkinliklerinde de bu beceriler ölçülmelidir (Temiz ve Tan, 2009).

Bilimsel süreç becerileri temel, nedensel ve deneysel olmak üzere üçe ayrılır. Temel beceriler gözlem yapma, ölçme, sınıflama, verileri kaydetme, sayı ve uzay ilişkisi kurma; nedensel beceriler önceden kestirme, değişkenleri belirleme, sonuç çıkarma (yordama); deneysel beceriler hipotez kurma, model oluşturma, deney yapma, değişkenleri değiştirme ve kontrol etme, karar verme olarak ifade edilmektedir (Akdeniz, 2011). Bilimsel süreç becerilerinden biri olan değişkenleri belirleme hem fen ve fizik derslerinde hem de günlük hayatın hemen her alanında kullanılmaktadır (Temiz ve Tan, 2009). Değişkenleri belirleme becerisi bir durum ya da olayı etkileyebilecek tüm faktörleri ortaya çıkarmayı ve farklı koşullarda değişen veya sabit kalan faktörlerin özelliklerini tanımayı kapsamaktadır. Bir olayı etkileyen değişkenleri belirlemek ve bu değişkenleri test etmek araştırma süreçleri için son derece önemlidir (Akdeniz, 2011). Bir sonucu etkileyen birden fazla değişken olabilir. Ortaya çıkan bir sonucun nedenini anlamak ya da yapılacak değişikliğin sonuç üzerindeki etkilerini görebilmek için söz konusu değişken dışındaki değişkenler belirlenmeli ve deney düzeneği bu doğrultuda hazırlamalıdır. $\mathrm{Bu}$ bağlamda deney yaparken değişkenleri belirlemek, kontrol edilmesi ya da sabit tutulması gereken verileri tanımlamak çok önemlidir (Bozkurt ve Olgun, 2005). Ancak alanyazın incelendiğinde ortaokul öğrencilerinin (Anagün ve Yaşar, 2009; Ayas-Kör, 2006; Böyük, Tanık ve Saraçoğlu, 2011; Durmaz ve Mutlu, 2012; Keser ve Başak, 2013; Ocak ve Tümer, 2014), 13-16 yaş aralığındaki öğrencilerin (Griffiths ve Thompson, 1993), lise 1. sınıf öğrencilerinin (Temiz ve Tan, 2009), 2. sınıfta (Bağcı-Kılıç, Yardımcı ve Metin, 2009), 3. sınıfta (Ateş, 2005; Ateş ve Bahar, 2002), son sınıfta öğrenim gören sinıf öğretmeni adaylarının (Laçin-Şimşek, 2010), son sınıf fen bilgisi öğretmen adaylarının (Aydoğdu, 2012; Harman ve Çökelez, 2016), son sınıf biyoloji, sınıf, fen ve teknoloji öğretmen adaylarının (Saka, 2012) bağımlı, bağımsız ve kontrol edilen değişkenleri birbiriyle karıştırdıkları, değişken türlerini birbirinin yerine kullandıkları ve değişkenleri belirleme becerilerinin yetersiz olduğu görülmektedir. Alanyazındaki araştırmalarda ortaya koyulan sonuçlar değişken türlerinin ve değişkenleri belirlemenin öğretiminde dikkat çekici materyaller kullanılarak ilgi çekici ve eğlenceli etkinliklerle somut uygulamalar yapılmasının gerekli olduğunu ortaya koymaktadır. Bu şekilde 
öğrenme ve öğrenilen bilgilerin kalıcılığını sağlamak mümkün olabilecektir. Bunu sağlayabilecek öğretim araçlarından biri de analojilerdir.

Analojiler; kavram, ilke ve formüllerin benzer özellikleri arasında kurulan sağlam bağlantılar olup, kaynak olarak nitelendirilen ön bilgiler ile hedef olarak nitelendirilen yeni bilgiler arasında kurulan güçlü köprülerdir (Kesercioğlu, Y1lmaz, Huyugüzel-Çavaş ve Çavaş, 2004). Analojiler bilginin yapılandırılma sürecini kolaylaştıran, kavramsal değişimi anlamayı sağlayan, kavramsal değişimle bireye yeni bakış açıları kazandıran, konu ile gerçek dünya arasındaki benzerliklere dikkat çekerek soyut anlamayı kolaylaştıran, kavramları görselleştiren, ilgi çekici, motive edici güçlü araçlardır (Duit, 1991). Analojiler somut örneklerle soyut durumları anlaş1lır hale getirirler (Ekici, Ekici ve Aydın, 2007). Hedef kavramın etki alanlarını tanıdık hale getirerek öğrenmeyi kolaylaştırırlar (Duit, 1991). Belleği yapılandırarak yeni bilgiler için hazırlarlar (Gentner, 1983). Ayrıca ön bilgilerin ve kavram yanılgılarının belirlenmesinde de etkilidirler (Duit, 1991). Bu nedenle bu araştırmada lamba parlaklığını etkileyen değişkenler ile değişkenleri belirlemenin öğretiminde analoji kullanımının öğrenme ve kavram yanılgılarının giderilmesi üzerindeki etkilerinin incelenmesi hedeflenmiştir.

\section{YÖNTEM}

Araştırmada yarı deneysel desen çeşitlerinden eşitlenmemiş kontrol gruplu ön ve son test desen kullanılmıştır. Katılımcıların düşüncelerini ayrıntılı bir şekilde ortaya koyabilmek ve daha detaylı bilgi alabilmek amacıyla veri toplama aracındaki sorular yöneltilerek deney ve kontrol gruplarındaki beşer öğrenciyle bireysel yarı yapılandırılmış görüşmeler yapılmıştır.

\section{Çalışma Grubu}

Araştırmanın çalışma grubunu 2013-2014 eğitim-öğretim yılının ikinci döneminde Samsun ilinde MEB'na bağlı bir devlet okulunda 5. sınıfta öğrenim görmekte olan 98 öğrenci oluşturmaktadır.

Tablo 1. Öğrencilerin cinsiyetleri için frekans dağılımı

\begin{tabular}{lccc}
\hline & Erkek öğrenci & Kız öğrenci & Toplam \\
\hline Deney Grubu & 20 & 29 & 49 \\
\hline Kontrol Grubu & 25 & 24 & 49 \\
\hline Toplam & 45 & 53 & 98 \\
\hline
\end{tabular}


G. Harman ve A. Çökelez / Eğitim Fakültesi Dergisi 32 (1), 2019, 63-91

\section{Uygulama}

Deney grubuyla yapılacak uygulamadan önce 25 beşinci sınıf öğrencisiyle pilot uygulama yapılmıştır.

Her iki grupta da uygulamalar araştırmacı tarafından yapılan bilgilendirmelerle aynı öğretmen tarafından gerçekleştirilmiştir. Araştırmacı deney ve kontrol gruplarının tüm derslerine gözlemci olarak katılmıştır. Her ders öncesinde öğretmenle 15-20 dakikalık bir ön çalışma yapılmıştır.

Deney grubundaki 49 öğrenciyle 2 ders saati süresince Pnömatik Sistem Modeli (PSM) 1-2-3 ile Basit Elektrik Devresi (BED) 1-2-3 arasında karşılaştırmalar yapılarak bağımlı, bağımsız ve kontrol edilen değişkenlerin öğretimine yönelik uygulama yapılmıştır.
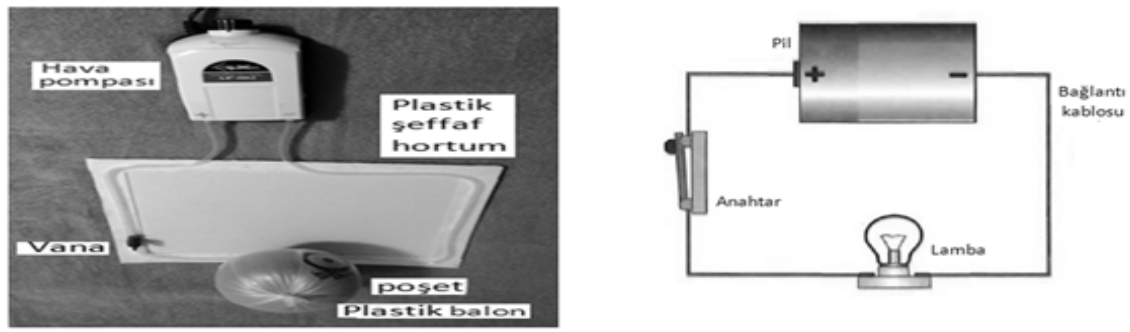

Şekil 1. PSM ve BED

PSM'deki (Harman ve Çökelez, 2015) elemanların BED’de hangi devre elemanına karşılık geldiği sorulmuştur. Tablo 2'de verilen kaynak ve hedef kavramlar arasındaki analojik ilişki öncelikle öğrenciler, daha sonra da öğretmen tarafından ifade edilmiştir.

Tablo 2. Kaynak ve hedef kavramlar arasındaki analojik ilişki

\begin{tabular}{ll}
\hline Kaynak Kavramlar & Hedef Kavramlar \\
\hline Hava pompası & Pil \\
\hline Plastik şeffaf hortum & Bağlantı kablosu \\
\hline Vana & Anahtar \\
\hline Plastik balon & Lamba \\
\hline Plastik balonun şişmesi & Lambanın yanması \\
\hline Plastik balonun şişme büyüklüğü & Lambanın parlaklığı \\
\hline
\end{tabular}


Analojilerde kaynak kavramlar ile hedef kavramlar arasinda benzerliklerin yanı sıra farklılıklar da olabilir. Kavram yanılgısı oluşumunu engellemek için bu farklılıkların ifade edilmesi gereklidir (Duit, 1991; Kesercioğlu vd., 2004). Bu nedenle öğretim sırasında kaynak kavramlar ile hedef kavramlar arasındaki farklılıklar ifade edilmiştir. BED'de elektrik akımı pile geri dönerken PSM'de hava pompaya geri dönmez. BED'de lambanın yanması için pil devreden ayrılmaz. PSM'de ise sistemi sabitlemek için hava pompası durdurulur. BED'de lambanın yanması için anahtar kapalı, PSM'de plastik balonun şişmesi için vana açı olmalıdır. PSM' de hava pompasından yayılan hava tek bir yol izleyerek plastik balona ulaşır ve plastik balonlar arasında hava akışı olmaz. Bir plastik balondan diğerine hava geçişi olmaz. Fakat devrede lambalar arasında akım akışı olur. Bir lambadan diğerine akım geçer (Harman ve Çökelez, 2015).

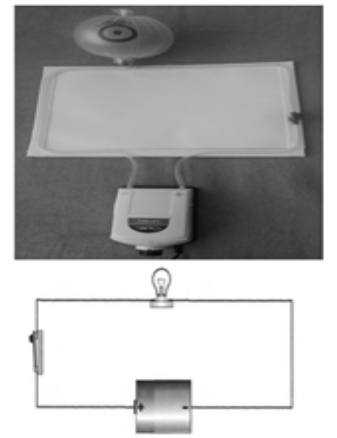

PSM 1 ve BED 1

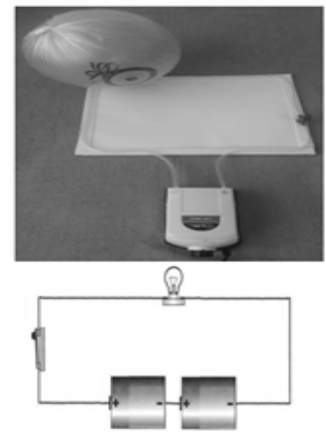

PSM 2 ve BED 2

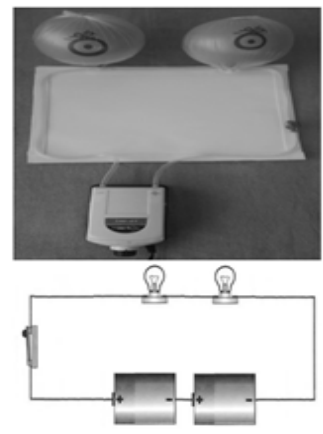

PSM 3 ve BED 3

Şekil 2. PSM 1-2-3 ve BED 1-2-3

Deney grubundaki öğrencilere bağımlı, bağımsız ve kontrol edilen değişken kavramları açıklanmıştır. Şekil 2'deki PSM 1-2-3 ile BED 1-2-3'ü inceleyen öğrencilerden PSM 1-PSM 2, PSM 2-PSM 3, BED 1-BED 2 ve BED 2-BED 3 arasında karşılaştırmalar yaparak bağımlı, bağımsız ve kontrol edilen değişkenleri ifade etmeleri istenmişstir. Daha sonra öğretmen PSM 1-2-3 ile BED 1-2-3 için bağımlı, bağımsız ve kontrol edilen değişken kavramlarını aşağıdaki tabloda verildiği şekilde öğrencilere açıklamıştır. Hava pompası PSM 1'de devir 1'de, PSM 2 ve PSM 3'te ise devir 2'de (seri bağlı 2 pili temsilen) çalıştırılmıştır. 
G. Harman ve A. Çökelez / Eğitim Fakültesi Dergisi 32 (1), 2019, 63-91

Tablo 3. PSM ve BED için bağımsız, kontrol edilen ve bağımlı değişkenler

\begin{tabular}{lll}
\hline Değişken türü & PSM 1-PSM 2 (BED 1-BED 2) & PSM 2-PSM 3 (BED 2-BED 3) \\
\hline \multirow{2}{*}{ Bağımsız } & $\begin{array}{l}\text { hava pompasının çalıştırıldığı devir } \\
\text { (pil sayısı) }\end{array}$ & $\begin{array}{l}\text { plastik balon sayısı } \\
\text { (lamba sayısı) }\end{array}$ \\
\hline \multirow{2}{*}{ Kontrol edilen } & $\begin{array}{l}\text { plastik balon sayısı } \\
\text { (lamba sayısı) }\end{array}$ & $\begin{array}{l}\text { hava pompasının çalıştırıldığı devir } \\
\text { (pil sayısı) }\end{array}$ \\
\hline \multirow{2}{*}{ Bağımlı } & $\begin{array}{l}\text { plastik balonun şişme büyüklüğü } \\
\text { (lamba parlaklığı) }\end{array}$ & $\begin{array}{l}\text { plastik balonun şişme büyüklüğü } \\
\text { (lamba parlaklığı) }\end{array}$ \\
\hline
\end{tabular}

Kontrol grubunda ders öğretim programı dikkate alınarak analoji (PSM) kullanılmadan işlenmiştir. Öğrencilere bağımlı, bağımsız ve kontrol edilen değişken kavramları açıklanmıştır. BED 1-2-3’ü inceleyen öğrencilerden bu devrelerdeki değişkenleri belirlemeleri ve bağıml, bağımsız ve kontrol edilen değişkenleri BED 1-BED 2 ve BED 2-BED 3 arasında karşılaştırmalar yaparak ifade etmeleri istenmiştir. Daha sonra öğretmen BED 1-2-3 için bağımlı, bağımsız ve kontrol edilen değiş̧ken kavramlarını öğrencilere açıklamıştır.

\section{Veri Toplama Aracı}

Öğretim programı incelenip, ulusal ve uluslararası alanyazın taraması yapılarak veri toplama aracı hazırlanmıştır. Hazırlanan veri toplama aracındaki ifadelerin kapsam geçerliliği ile öğrencilerin konuyla ilgili bilgilerini saptama yeterliliği, gerekli olmayan, düzeltme gerektiren ya da anlaşılmayan herhangi bir ifade olup olmadığ1, öğrenci düzeyi ve kazanımlara uygun olup olmadığı hususunda mesleki deneyimleri 6-25 y11 arasında değişen 8 fen ve teknoloji öğretmeni ile alanı fen ve fizik eğitimi olan 3 ögrretim üyesinden; dilbilgisi ve anlaşılırlık açısından da bir dil uzmanından görüş alınmıştır. Veri toplama aracındaki ifadelerin anlaşılırlığını, görünüş geçerliliği bakımından uygunluğunu ve cevaplama süresini belirlemek için 42 altıncı sınıf öğrencisiyle pilot uygulama yapılmıştır. Uzman görüşleri ve pilot uygulama neticesinde son hali verilen veri toplama aracı ile 5. sınıf öğrencilerine bağımlı, bağımsız ve kontrol edilen değişkenleri gerekçeleri ile ifade etmelerinin istendiği 3 ayrı durum sunulmuş ve her durum için 3 soru olmak üzere toplam 9 soru (Bkz: Ek) yöneltilmiştir.

\section{Verilerin Analizi}

Araştırma neticesinde elde edilen veriler içerik analizi ile çözümlenmiştir. İçerik analizi yapılan veriler (1) Verilerin kodlanması, (2) Temaların oluşturulması, (3) Verilerin kodlara ve temalara göre 
düzenlenmesi ve tanımlanması, (4) Bulguların yorumlanması olmak üzere 4 aşamada çözümlenmiştir (Yıldırım ve Şimşek, 2011).

Öğrencilerin cevap kâğıtları numaralandırılmış, cevapları incelenmiş ve her soru için tek tek yazılmıştır. Veri analizi için araştırmanın kavramsal çerçevesinde ve araştırma sorularında yer alan boyutlar göz önünde bulundurularak araştırma öncesinde oluşturulan çerçeve bağlamında veriler okunmuştur. Ayrıca önceden belirlenen çerçeveye uygulama sonunda saptanan yeni ifadelerde dâhil edilmiştir. Veriler anlamlı ve mantıklı olacak şekilde birleştirilmiş ve tanımlanmıştır. Tanımlanan veriler açıklanmış, ilişkilendirilmiş ve anlamlandırılmıştır. Veriler için frekans ve yüzde değerleri hesaplanmıştır. Frekans ve yüzde değerleri kullanılarak hazırlanan tablolar yorumlanmıştır. Öğrencilerin ifadelerini açık ve net bir biçimde yansıtabilmek için doğrudan alıntılara yer verilmiştir.

\section{BULGULAR}

Öğrencilerin verdikleri cevaplar analiz edilerek 4, .., 12 nolu tablolarda sunulmuştur.

Lamba sayısının lamba parlaklığı üzerindeki etkisinin araştırıldığ bir deneyin bağımlı değişkeni (cevap veren değişken) için frekans ve yüzde değerleri Tablo 4'te verilmiştir. (Bkz: Ek. Soru 1A)

Tablo 4. Bağımlı değişken (cevap veren değişken)

\begin{tabular}{|c|c|c|c|c|c|c|c|c|}
\hline & \multicolumn{4}{|c|}{ ÖN TEST } & \multicolumn{4}{|c|}{ SON TEST } \\
\hline & \multicolumn{2}{|c|}{ DG } & \multicolumn{2}{|c|}{ KG } & \multicolumn{2}{|c|}{ DG } & \multicolumn{2}{|c|}{ KG } \\
\hline & $\mathbf{f}$ & $\%$ & f & $\%$ & f & $\%$ & $\mathbf{f}$ & $\%$ \\
\hline Lamba parlaklığ $1 *$ & 13 & 26,5 & 12 & 24,5 & 37 & 75,5 & 25 & 51,0 \\
\hline Lamba say1s1 & 9 & 18,4 & 7 & 14,3 & 5 & 10,2 & 7 & 14,3 \\
\hline Pil say1s1 & 4 & 8,2 & 3 & 6,1 & - & - & 7 & 14,3 \\
\hline Pil sayısı ve lamba sayısı & - & - & 1 & 2,0 & - & - & - & - \\
\hline Lambanın pile yakınlığ 1 & - & - & 1 & 2,0 & - & - & - & - \\
\hline Anahtarın kapalı olması & 1 & 2,0 & 2 & 4,1 & - & - & 1 & 2,0 \\
\hline Boş & 22 & 44,9 & 23 & 46,9 & 7 & 14,3 & 9 & 18,4 \\
\hline TOPLAM & 49 & 100 & 49 & 100 & 49 & 100 & 49 & 100 \\
\hline
\end{tabular}

*: Doğru

Tablo incelendiğinde ön testte doğru cevap veren öğrenci sayısının iki grupta neredeyse aynı olduğu, son testte ise doğru cevap veren öğrenci sayısının deney grubunda daha fazla olduğu görülmektedir. 
Doğru cevaptan sonra deney ve kontrol grupları tarafindan ön ve son testte en çok ifade edilen cevabın "lamba sayısı" olduğu görülmüştür. Öğrenciler "Lamba parlaklığı lamba sayısına bağlıdır." gerekçesiyle bağımlı değişkeni lamba sayısı olarak ifade etmiştir. Ön testte deney grubunda 4, kontrol grubunda 3 öğrenci "Parlaklık pil sayısına bağlıdır." gerekçesiyle pil sayısını bağımlı değişken olarak ifade etmiştir. Öğretim sonunda deney grubunda görülmeyen yanılg1 kontrol grubunda 7 öğrencide görülmüştür. $\mathrm{Bu}$ bulgulardan öğrencilerin bağlı ve bağımlı kavramları arasında yanılgılı bir ilişki kurdukları anlaşıılmaktadır.

Kontrol grubundaki 1 öğrenci ön testte "Pile yakın olan lamba en parlak yanar. İlk lamba daha parlak yanar." gerekçesiyle lambanın pile yakınlığını bağımlı değişken olarak ifade etmiştir. Öğrenci parlaklığın lamba ile pil arasındaki mesafeye bağlı olarak değişeceğini, devrede pile ya da güç kaynağına en yakın olan lambanın diğerlerine göre daha parlak yanacağını düşünmektedir. Öğrencide "Devrede pile yakın olan lamba enerjinin tamamını alır ve kullanır. İlk lambadan sonra gelen lambaya daha az enerji düşer." kavram yanılgısı mevcuttur.

Yapılan görüşmelerde bazı öğrencilerin "Devreden elektrik geçmesi anahtarın kapalı olmasına bağlıdır.” gerekçesiyle anahtarı bağımlı değişken olarak ifade etmeleri dikkat çekicidir. Bu gerekçeden öğrencilerin lambanın yanması için kapalı olması gereken anahtarı lamba parlaklığını etkileyen bir değişken olarak gördükleri anlaşılmaktadır.

Lamba sayısının lamba parlaklığı üzerindeki etkisinin araştırıldığ bir deneyin bağımsız değişkeni (değiştirilen değişken) için frekans ve yüzde değerleri Tablo 5'te verilmiştir. (Bkz: Ek. Soru 1B)

Tablo 5. Bağımsız değişken (değiştirilen değişken)

\begin{tabular}{lcccccccc}
\hline & \multicolumn{4}{c}{ ÖN TEST } & \multicolumn{5}{c}{ SON TEST } \\
\cline { 2 - 10 } & \multicolumn{3}{c}{ DG } & \multicolumn{2}{c}{ KG } & \multicolumn{2}{c}{ DG } & \multicolumn{2}{c}{ KG } \\
\cline { 2 - 10 } & f & $\mathbf{\%}$ & f & \% & f & \% & f & \% \\
\hline Lamba sayıs1* & 13 & 26,5 & 22 & 44,9 & 36 & 73,5 & 26 & 53,1 \\
\hline Pil sayıs1 & 7 & 14,2 & 8 & 16,4 & 9 & 18,4 & 12 & 24,5 \\
\hline Lamba parlaklığ1 & 3 & 6,1 & 5 & 10,2 & - & - & 3 & 6,1 \\
\hline Lambanın pile yakınlığ1 & - & - & 1 & 2,0 & - & - & - & - \\
\hline Anahtarın açık/kapalı olmas1 & 4 & 8,2 & - & - & - & - & 2 & 4,1 \\
\hline Bağlantı kablosunun sağlamlığ1 & 1 & 2,0 & 1 & 2,0 & - & - & - & - \\
\hline Boş & 21 & 42,9 & 12 & 24,5 & 4 & 8,2 & 6 & 12,2 \\
\hline TOPLAM & $\mathbf{4 9}$ & $\mathbf{1 0 0}$ & $\mathbf{4 9}$ & $\mathbf{1 0 0}$ & $\mathbf{4 9}$ & $\mathbf{1 0 0}$ & $\mathbf{4 9}$ & $\mathbf{1 0 0}$ \\
\hline
\end{tabular}

*: Doğru 
Tablo incelendiğinde doğru cevap veren öğrenci sayısının ön testte kontrol, son testte deney grubunda daha fazla olduğu görülmektedir. Öğrenciler "Lamba sayısı değişeceği için" gerekçesiyle lamba sayısının bağımsız değişken olduğunu belirtmiştir.

Doğru cevaptan sonra deney ve kontrol grupları tarafindan ön ve son testte en çok ifade edilen cevabın pil sayısı olduğu görülmüştür. Görüşmelerde öğrenci "Pil sayısını değiştirecem. Bağımsız değişken olur. Pil lambaya enerji veriyor. Pil gittikçe azalıyor. Sonra da pil bitiyor. $\mathrm{Bu}$ yüzden sayısı değiştiği için bağımsız değişken. 2 tane pil varken 1 pili çıkarırsak parlaklık azalır. Lamba az yanar. Pil 1 tane olunca hemen biter.” ifadesiyle cevabını gerekçelendirmiştir. Buradan bazı öğrencilerin bağımsız değişken ile kontrol edilen değişken kavramlarını birbirine karıştırdıkları anlaşılmaktadır.

Ön testte deney grubunda 3, kontrol grubunda 5 öğrenci "Lamba parlaklığı değişecek” gerekçesiyle lamba parlaklığını bağımsız değişken olarak ifade etmiştir. Bu yanılgı ögretim sonunda sadece kontrol grubunda 3 ögrencide saptanmıştır.

Kontrol grubundaki 1 öğrenci ön testte "Pile yakın olan lamba en parlak yanar. İlk lamba daha parlak yanar." gerekçesiyle lambanın pile yakınlığını bağımsız değişken olarak ifade etmiştir. Buradan öğrencinin lamba ile pil arasındaki mesafenin değiştirilmesi sonucunda lamba parlaklığının değişeceğini düşündüğü anlaşılmaktadır. Öğrencide enerjinin pilden ilk çıktığı noktada daha fazla olup devrede hareketine başladıktan sonra değerinin azalmaya başlayacağına yönelik kavram yanılgısı mevcuttur. Öğrenci pile yakın olan lambanın pilden çıkan enerjinin ilk haliyle daha yüksek değerini alarak parlak yanacağına inanmaktadır.

Anahtarın bağımsız değişken olduğunu belirten öğrencilerin “Anahtar kapalı olunca elektrik geçer, açıkken geçmez." şeklinde ifade ettikleri gerekçeden anahtarın açık ya da kapalı olma durumunda yapılacak değişikliğin lamba parlaklığını etkileyeceğini düşündükleri anlaşılmaktadır. Öğrenciler "Anahtar kapalı iken elektrik geçer, açıkken elektrik geçmez." gerekçesiyle anahtarın açık-kapalı olmasını isteklerine bağlı olarak değiştirebilmeleri nedeni ile anahtarı bağımsız değişken olarak ifade etmişlerdir. Bu bulgudaki yanılgı öğrencilerin lambanın $1 s ̧ 1 \mathrm{k}$ vermesi için gereken temel koşullardan birini lamba parlaklığını etkileyen bir değişken olarak kabul etmeleridir.

Ön testte deney ve kontrol gruplarından birer öğrenci için bağlantı kablosunun sağlamlığı bağımsız değişkendir. Bu öğrenciler lambanın 1şık 
vermesi için yerine getirilmesi gereken bağlantı kablolarında kopukluk ya da eksiklik olmamalı koşulunu lamba parlaklığını etkileyen bir değişken olarak kabul etmektedir. Öğrencilerin bağlantı kablolarının sağlam olmasını bağımsız değişken olarak kabul etmeleri bağlantı kablosunda kopukluk olması durumunda da lambanın yanacağına; ancak parlaklığın azalacağına inandıklarını ortaya koymaktadır.

Lamba sayısının lamba parlaklığı üzerindeki etkisinin araştırıldığ bir deneyin kontrol edilen değişkeni (sabit tutulan değişken) için frekans ve yüzde değerleri Tablo 6'da verilmiştir. (Bkz: Ek. Soru 1C)

Tablo 6. Kontrol edilen değişken (sabit tutulan değişken)

\begin{tabular}{|c|c|c|c|c|c|c|c|c|}
\hline & \multicolumn{4}{|c|}{ ÖN TEST } & \multicolumn{4}{|c|}{ SON TEST } \\
\hline & \multicolumn{2}{|c|}{ DG } & \multicolumn{2}{|c|}{ KG } & \multicolumn{2}{|c|}{ DG } & \multicolumn{2}{|c|}{ KG } \\
\hline & f & $\%$ & f & $\%$ & f & $\%$ & f & $\%$ \\
\hline Pil sayısı* & 9 & 18,4 & 12 & 24,5 & 35 & 71,4 & 24 & 49,0 \\
\hline Lamba sayıs1 & 7 & 14,3 & 6 & 12,2 & 8 & 16,3 & 10 & 20,4 \\
\hline $\begin{array}{l}\text { Lamba sayısı, anahtar sayısı, bağlantı } \\
\text { kablosunun sağlamlığı }\end{array}$ & 1 & 2,0 & 1 & 2,0 & - & - & 1 & 2,0 \\
\hline Lamba parlaklığ1 & 2 & 4,1 & 2 & 4,1 & 1 & 2,0 & 4 & 8,2 \\
\hline Lambanın pile yakınlı̆̆ & - & - & 1 & 2,0 & - & - & - & - \\
\hline Anahtar sayısı & 5 & 10,2 & 6 & 12,2 & - & - & 3 & 6,1 \\
\hline Bağlantı kablosunun sağlamlığ & 2 & 4,1 & 2 & 4,1 & - & - & 1 & 2,0 \\
\hline $\begin{array}{lll}\text { Bağlant1 kablosunun sağlamlığ } & \text { ve } \\
\text { anahtar sayıs1 } & & \\
\end{array}$ & - & - & 2 & 4,1 & - & - & - & - \\
\hline Boş & 23 & 46,9 & 17 & 34,7 & 5 & 10,2 & 6 & 12,2 \\
\hline TOPLAM & 49 & 100 & 49 & 100 & 49 & 100 & 49 & 100 \\
\hline
\end{tabular}

*: Doğru

Tablo incelendiğinde ön testte doğru cevap veren öğrenci sayısının iki grupta birbirine yakın olduğu, son testte doğru cevap veren öğrenci sayısının deney grubunda daha fazla olduğu görülmektedir. Öğrenciler "Pil sayısı değişmeyeceği için” gerekçesiyle pil sayısının kontrol edilen değişken olduğunu ifade etmiştir.

Doğru cevaptan sonra deney ve kontrol gruplarında ön ve son testte en çok ifade edilen cevabın lamba sayısı olduğu görülmüştür. Öğrenciler "Lamba sayısı aynı tutulup 1şığına bakılır." gerekçesiyle kontrol edilen değişkenin lamba sayısı olduğunu ifade etmiştir. Bu durum bazı öğrencilerin kontrol edilen değişken ile bağımsız değişken kavramlarını birbirine 
karıştırdıklarını ortaya koymaktadır. Öğrenciler lamba sayısının aynı tutularak lamba parlaklığına bakılması gerektiğini düşünmektedir. Deney ve kontrol gruplarındaki öğrencilerin kontrol edilen değişken yerine bağımsız değişkeni yazmaları ve bu oranın son test sonuçlarındaki artışı dikkat çekicidir.

Bazı öğrenciler "Lambanın pile yakınlığı hep aynı olmalı" gerekçesiyle lambanın pile yakınlığını; "Anahtar sayısı devrede hep aynı olacak 1 tane olacak" gerekçesiyle anahtar sayısını ve "Lambanın parlak yanması için bağlantı kablosu hep sağlam olmalı" gerekçesiyle bağlantı kablosunun sağlamlığını kontrol edilen değişken olarak ifade etmişlerdir. Görüşmelerde ise öğretimden sonra kontrol grubunda yer alan bir öğrenci "Anahtar. Kontrol ediyor devrenin açılıp kapanmasını." gerekçesiyle anahtarı kontrol edilen değişken olarak belirtmiştir. Lambanın pile yakınlığı, anahtar sayısı ve bağlantı kablosunun sağlamlığı öğretim öncesinde deney ve kontrol gruplarında kontrol edilen değişken olarak ifade edilirken öğretim sonunda bu yanılgı sadece kontrol grubunda saptanmıştır.

Pil sayısının sabit tutularak lamba sayısının değiştirildiği bir deneyin bağımlı değişkeni (cevap veren değişken) için yüzde ve frekans değerleri Tablo 7'de verilmiştir. (Bkz: Ek. Soru 2A)

Tablo 7. Bağımlı değişken (cevap veren değişken)

\begin{tabular}{lcccccccc}
\hline & \multicolumn{4}{c}{ ÖN TEST } & \multicolumn{3}{c}{ SON TEST } \\
\cline { 2 - 10 } & \multicolumn{2}{c}{ DG } & \multicolumn{2}{c}{ KG } & \multicolumn{2}{c}{ DG } & \multicolumn{2}{c}{ KG } \\
\cline { 2 - 10 } & f & $\mathbf{\%}$ & f & \% & f & \% & f & \% \\
\hline Lamba parlaklı̆̆1* & 14 & 28,6 & 10 & 20,4 & 40 & 81,6 & 29 & 59,2 \\
\hline Lamba sayıs1 & 9 & 18,4 & 7 & 14,3 & 4 & 8,2 & 8 & 16,3 \\
\hline Pil sayıs1 & 3 & 6,1 & 7 & 14,3 & 1 & 2,0 & 7 & 14,3 \\
\hline Pil sayısı ve lamba sayıs1 & - & - & 1 & 2,0 & - & - & 1 & 2,0 \\
\hline $\begin{array}{l}\text { Pil sayı11 ve anahtarın açık/kapalı } \\
\text { olmas1 }\end{array}$ & - & - & - & - & 1 & 2,0 & - & - \\
\hline Bağlantı kablosunun sağlamlığ1 & 2 & 4,1 & 1 & 2,0 & - & - & - & - \\
\hline Anahtarın açık/kapalı olması & 1 & 2,0 & 2 & 4,1 & - & - & - & - \\
\hline Boş & 20 & 40,8 & 21 & 42,9 & 3 & 6,1 & 4 & 8,2 \\
\hline TOPLAM & $\mathbf{4 9}$ & $\mathbf{1 0 0}$ & $\mathbf{4 9}$ & $\mathbf{1 0 0}$ & $\mathbf{4 9}$ & $\mathbf{1 0 0}$ & $\mathbf{4 9}$ & $\mathbf{1 0 0}$ \\
\hline
\end{tabular}

*: Doğru

Tablo incelendiğinde ön testte doğru cevap veren öğrenci sayısının deney grubunda kontrol grubuna nazaran az bir farkla fazla olduğu, son 
testte deney grubunda doğru cevap veren öğrenci sayısının kontrol grubundan daha fazla olduğu görülmektedir.

Doğru cevaptan sonra deney ve kontrol gruplarında ön ve son testte en çok ifade edilen cevabın lamba sayısı olduğu görülmüştür. Bu durum bazı öğrencilerin bağımlı değişken ile bağımsız değişken kavramlarını birbirine karıştırdıklarını ortaya koymaktadır. Bu yanılgı son testte deney grubunda \% 8,2'ye düşerken kontrol grubunda \% 16,3'e ç1kmıştır.

Ön testte deney grubundaki 3, kontrol grubundaki 7 öğrenci "Lamba parlaklığı pil sayısına bağlıdır. Pil sayısı değişmemiştir.” gerekçesiyle pil sayısını bağımlı değişken olarak ifade etmiştir. Buradan öğrencilerin değişmeyen şeylerin bağımlı değişken olduğunu düşündükleri anlaşılmaktadır. $\mathrm{Bu}$ yanılgı son testte deney grubunda azalarak 1, kontrol grubunda 7 öğrencide yine saptanmıştır.

Kontrol grubunda ön ve son testte 1 öğrenci "Lamba parlaklığı pil ve lamba sayısına bağlıdır." gerekçesiyle pil sayısı ve lamba sayısını bağımlı değişken olarak ifade etmiştir. Buradan öğrencilerin bağımlı ile bağlı kelimeleri arasında yanılgılı bir ilişki kurarak lamba parlaklığının bağlı olduğu değişkenleri bağımlı değişken olarak yazdıkları anlaşılmaktadır.

Ön testte deney grubunda 1, kontrol grubunda 2 öğrenci, son testte deney grubunda 1 öğrenci "Lambanın yanması anahtara bağlıdır." gerekçesiyle anahtarı bağımlı değişken olarak ifade etmiştir. Ön testte deney grubunda 2, kontrol grubunda 1 öğrenci bağlantı kablosunun sağlam olmasını bağımlı değişken olarak ifade etmiştir. Öğrencilerdeki yanılg1 lambanın yanması için gereken temel koşuların parlaklığını da etkileyeceğini düşünmelerinden kaynaklanmaktadır. Öyle ki, lambanın yanması için anahtarın kapalı ve bağlantı kablolarının da sağlam olması zorunludur. Ayrıca öğrencilerin lambanın yanmasının anahtarın kapalı ve kablonun sağlam olmasına bağlı olma durumunu bağlı ve bağımlı kelimeleri arasında yanılgılı bir ilişki kurarak bağımlı değişken olarak yazdıkları düşünülmektedir. Öğretim sonunda bu yanılgılar giderilmiştir.

Pil sayısının sabit tutularak lamba sayısının değiştirildiği bir deneyin bağımsız değişkeni (değiştirilen değişken) için yüzde ve frekans değerleri Tablo 8'de verilmiştir. (Bkz: Ek. Soru 2B) 
G. Harman ve A. Çökelez / Eğitim Fakültesi Dergisi 32 (1), 2019, 63-91

Tablo 8. Bağımsız değişken (değiştirilen değişken)

\begin{tabular}{|c|c|c|c|c|c|c|c|c|}
\hline & \multicolumn{4}{|c|}{ ÖN TEST } & \multicolumn{4}{|c|}{ SON TEST } \\
\hline & \multicolumn{2}{|c|}{ DG } & \multicolumn{2}{|c|}{ KG } & \multicolumn{2}{|c|}{ DG } & \multicolumn{2}{|c|}{ KG } \\
\hline & f & $\%$ & f & $\%$ & f & $\%$ & $\mathbf{f}$ & $\%$ \\
\hline Lamba sayısı* & 23 & 46,9 & 24 & 49,0 & 44 & 89,8 & 35 & 71,4 \\
\hline Pil sayıs1 & 7 & 14,3 & 5 & 10,2 & 1 & 2,0 & 4 & 8,2 \\
\hline Lamba parlaklığ 1 & 5 & 10,2 & 2 & 4,1 & 1 & 2,0 & 2 & 4,1 \\
\hline $\begin{array}{l}\text { Pil sayısı ve anahtarın açık/kapalı } \\
\text { olması }\end{array}$ & 1 & 2,0 & - & - & - & - & - & - \\
\hline Anahtarın açı/kapalı olması & - & - & - & - & - & - & 2 & 4,1 \\
\hline Boş & 13 & 26,5 & 18 & 36,7 & 3 & 6,1 & 6 & 12,2 \\
\hline TOPLAM & 49 & 100 & 49 & 100 & 49 & 100 & 49 & 100 \\
\hline
\end{tabular}

Tablo incelendiğinde doğru cevap veren öğrenci sayısının her iki grupta neredeyse aynı olduğu, son testte doğru cevap veren öğrenci sayısının deney grubunda daha fazla olduğu görülmektedir. Öğrenciler "Lambaların sayısı değişmiş olduğu için lamba bağımsız değişken” gerekçesiyle lamba sayısının bağımsız değişken olduğunu belirtmiştir.

Doğru cevaptan sonra deney ve kontrol grupları tarafindan ön ve son testte en çok ifade edilen cevabın "Pil sayısı değiştiği için" gerekçesiyle pil sayısı olduğu görülmüştür. Pil sayısını bağımsız değişken olarak ifade eden öğrenci sayıs1 deney grubunda 7'den 1'e, kontrol grubunda 5'ten 4'e düşmüştür.

Anahtarın açık ya da kapalı olması lambanın ışı verme durumunu etkilerken parlaklık üzerinde etkili değildir. Buna karşın bazı öğrencilerin "Anahtarın açık-kapalı olmasını ayarlayabiliriz." gerekçesiyle anahtarı bağımsız değişken olarak ifade etmeleri dikkat çekicidir. Öğretim öncesinde deney grubunda 1 ögrencide saptanan yanılgı giderilirken, kontrol grubunda 2 ögrencide kavram yanılgısı oluştuğu görülmüştür.

Pil sayısının sabit tutularak lamba sayısının değiştirildiği bir deneyin kontrol edilen değişkeni (sabit tutulan değişken) için yüzde ve frekans değerleri Tablo 9'da verilmiştir. (Bkz: Ek. Soru 2C) 
G. Harman ve A. Çökelez / Eğitim Fakültesi Dergisi 32 (1), 2019, 63-91

Tablo 9. Kontrol edilen değişken (sabit tutulan değişken)

\begin{tabular}{|c|c|c|c|c|c|c|c|c|}
\hline & \multicolumn{4}{|c|}{ ÖN TEST } & \multicolumn{4}{|c|}{ SON TEST } \\
\hline & \multicolumn{2}{|c|}{ DG } & \multicolumn{2}{|c|}{ KG } & \multicolumn{2}{|c|}{ DG } & \multicolumn{2}{|c|}{ KG } \\
\hline & f & $\%$ & f & $\%$ & f & $\%$ & f & $\%$ \\
\hline Pil sayıs1* & 19 & 38,8 & 17 & 34,7 & 44 & 89,8 & 35 & 71,4 \\
\hline Anahtar sayıs1 & 9 & 18,4 & 12 & 24,5 & 1 & 2,0 & 4 & 8,2 \\
\hline Lamba say1s1 & 1 & 2,0 & 2 & 4,1 & 1 & 2,0 & 1 & 2,0 \\
\hline Lamba parlaklı̆ 1 & 1 & 2,0 & - & - & - & - & 2 & 4,1 \\
\hline Bağlantı kablosunun sağlamlığı & 4 & 8,2 & 3 & 6,1 & - & - & - & - \\
\hline Devrenin kapalı olması & - & - & - & - & - & - & 1 & 2,0 \\
\hline Boş & 15 & 30,6 & 15 & 30,6 & 3 & 6,1 & 6 & 12,2 \\
\hline TOPLAM & 49 & 100 & 49 & 100 & 49 & 100 & 49 & 100 \\
\hline
\end{tabular}

*: Doğru

Tablo incelendiğinde doğru cevap veren öğrenci sayısının her iki grupta birbirine yakın olduğu, son testte doğru cevap veren öğrenci sayısının deney grubunda daha fazla olduğu görülmektedir. Öğrenciler "İki devre için de pil sabit olduğu için kontrol edilen değişkendir.", "Pil. Çünkü piller hep aynı." gerekçeleriyle pil sayısının kontrol edilen değişken olduğunu belirtmiştir.

Doğru cevaptan sonra deney ve kontrol gruplarında ön ve son testte en çok ifade edilen cevabın "İki devrede de anahtar sayısı aynı" gerekçesiyle anahtar sayısı olduğu görülmüştür. Görüşmelerde öğretimden sonra kontrol grubunda yer alan 1 öğrenci "Anahtar. Çünkü devreleri kontrol ediyor." gerekçesiyle anahtarın kontrol edilen değişken olduğunu düşündüğünü ifade etmiş̧tir. Bu yanılgı deney grubunda 9'dan 1'e, kontrol grubunda 12'den 4'e düşmüştür.

Ön testte deney grubunda 4, kontrol grubunda 3 öğrenci kontrol edilen değişken olarak bağlantı kablosunun sağlam olmasını ifade etmiştir. $\mathrm{Bu}$ bulgu bağlantı kablosunun sağlam olmasının öğrenciler tarafından her iki devre için aynı olan bir değişken olarak algılandığını göstermektedir. Dahası bağlantı kablosunun sağlam olması lambanın yanması için temel koşuldur. $\mathrm{Bu}$ öğrencilerin bağlantı kablosu sağlam olmadığında ya da bağlantıda herhangi bir eksiklik olması durumunda da lambanın parlaklığının azalarak yanmaya devam edeceğini düşündükleri anlaşılmaktadır. Öyle ki, öğrencilerle yapılan görüşmelerde "Bağlantı kablosu sadece pilin artı kutbuna bağlanırsa lamba daha parlak yanar. Sadece negatif kutba bağlanırsa lamba daha az parlak yanar." şeklinde bağlantı kablosunun tam olmadığı ya 
da sağlam olmadığı durumlarda lambanın bağlı olduğu pil kutbuna bağlı olarak parlaklığının artacağı ya da azalacağına ilişkin düşünceler saptanmıştır. Ön testte saptanan bu yanılgı son testte iki grupta da görülmemiştir.

Kontrol grubundaki 1 öğrenci öğretim sonunda devrenin kapalı olmasını kontrol edilen değişken olarak ifade etmiştir. Bu durum şekillerde verilen iki devrenin kapalı olmasının öğrenci tarafından sabit bir gösterim olarak algılanmasından kaynaklanıyor olabilir. Ayrıca buradan öğrencinin devrenin kapalı bir sistem olmasının lamba parlaklığını etkileyen bir değişken olduğunu düşündüğü anlaşılmaktadır. Bu düşünce öğrencinin açık devre sisteminde de lambanın yanacağını kabul etmesine neden olabileceği için dikkat çekicidir.

Lamba sayısının sabit tutularak pil sayısının değiştirildiği bir deneyin bağımlı değişkeni (cevap veren değişken) için yüzde ve frekans değerleri Tablo 10'da verilmiştir. (Bkz: Ek. Soru 3A)

Tablo 10. Bağımlı değişken (cevap veren değişken)

\begin{tabular}{|c|c|c|c|c|c|c|c|c|}
\hline & \multicolumn{4}{|c|}{ ÖN TEST } & \multicolumn{4}{|c|}{ SON TEST } \\
\hline & \multicolumn{2}{|c|}{ DG } & \multicolumn{2}{|c|}{ KG } & \multicolumn{2}{|c|}{ DG } & \multicolumn{2}{|c|}{ KG } \\
\hline & f & $\%$ & f & $\%$ & $\mathbf{f}$ & $\%$ & f & $\%$ \\
\hline Lamba parlaklığ ${ }^{*}$ & 8 & 16,3 & 10 & 20,4 & 38 & 77,6 & 27 & 55,1 \\
\hline Lamba sayısı & 9 & 18,4 & 8 & 16,3 & 1 & 2,0 & 10 & 20,4 \\
\hline Pil sayıs1 & 6 & 12,2 & 9 & 18,4 & 2 & 4,1 & 2 & 4,1 \\
\hline Anahtarın açı/kapalı olması & 1 & 2,0 & 1 & 2,0 & 1 & 2,0 & 1 & 2,0 \\
\hline Bağlantı kablosunun sağlamlığ 1 & 1 & 2,0 & 1 & 2,0 & - & - & 1 & 2,0 \\
\hline Boş & 24 & 49,0 & 20 & 40,8 & 7 & 14,3 & 8 & 16,3 \\
\hline TOPLAM & 49 & 100 & 49 & 100 & 49 & 100 & 49 & 100 \\
\hline
\end{tabular}

*: Doğru

Tablo incelendiğinde ön testte doğru cevap veren öğrenci sayısının iki grupta birbirine yakın olduğu, son testte deney grubunda daha fazla olduğu görülmektedir. Öğrenciler "Parlaklık pil sayısından etkilendiği için" gerekçesi ile lamba parlaklığının bağımlı değişken olduğunu ifade etmiştir.

Doğru cevaptan sonra deney ve kontrol grupları tarafindan ön ve son testte en çok ifade edilen cevabın lamba sayısı olduğu görülmüştür. $\mathrm{Bu}$ durum özellikle kontrol grubundaki öğrencilerin son testte gerçekleşen artışla birlikte bağımlı değişken ile kontrol edilen değişken kavramlarını 
birbirine karıştırdıklarını ortaya koymaktadır. Lamba sayısını bağımlı değişken olarak ifade eden öğrenci sayısı deney grubunda 9'dan 1'e düşerken, kontrol grubunda 8'den 10'a çıkmıştır.

Bazı öğrenciler ise bağımlı değişken olarak pil sayısı cevabını vermiştir. $\mathrm{Bu}$ öğrenciler bağımlı değişken ile bağımsız değişkeni birbirine karıştırmaktadır. Pil sayısını bağımlı değişken olarak ifade eden öğrenci sayıs1 deney grubunda 6'dan, kontrol grubunda 9'dan 2'ye düşmüştür.

Her iki grupta da ön ve son testte birer öğrenci "Lambanın 1 şık vermesi anahtarın kapalı olmasına bağlı" gerekçesiyle anahtarı bağımlı değişken olarak ifade etmiştir. Ön testte deney ve kontrol gruplarından birer öğrenci "Lambanın 1şık vermesi için kablo sağlam olmalı" gerekçesi ile bağlantı kablosunun sağlam olmasını bağımlı değişken olarak ifade etmiştir. Öğrenciler devredeki lambanın 1şık vermesi için gerekli koşulları lamba parlaklığını etkileyen değişkenler olarak düşünmektedir. $\mathrm{Bu}$ kavram yanılgısı son testte deney grubunda giderilmiş, kontrol grubunda 1 öğrencide yine saptanmıştır.

Lamba sayısının sabit tutularak pil sayısının değiştirildiği bir deneyin bağımsız değişkeni (değiştirilen değişken) için yüzde ve frekans değerleri Tablo 11'de verilmiştir. (Bkz: Ek. Soru 3B)

Tablo 11. Bağımsız değişken (değiştirilen değişken)

\begin{tabular}{lcccccccc}
\hline & \multicolumn{4}{c}{ ÖN TEST } & \multicolumn{3}{c}{ SON TEST } \\
\cline { 2 - 10 } & \multicolumn{3}{c}{ DG } & \multicolumn{2}{c}{ KG } & \multicolumn{2}{c}{ DG } & \multicolumn{2}{c}{ KG } \\
\cline { 2 - 10 } & f & $\mathbf{\%}$ & f & \% & f & \% & f & \% \\
\hline Pil sayı1* & 31 & 63,3 & 29 & 59,2 & 43 & 87,8 & 35 & 71,4 \\
\hline Lamba sayıs1 & 2 & 4,1 & 1 & 2,0 & 2 & 4,1 & 2 & 4,1 \\
\hline Lamba parlaklığ1 & 2 & 4,1 & 2 & 4,1 & - & - & - & - \\
\hline Bağlantı kablosunun sağlamlığ1 & 1 & 2,0 & 1 & 2,0 & - & - & - & - \\
\hline Anahtarın açık/kapalı olması & - & - & 1 & 2,0 & - & - & 1 & 2,0 \\
\hline Boş & 13 & 26,5 & 15 & 30,6 & 4 & 8,2 & 11 & 22,4 \\
\hline TOPLAM & $\mathbf{4 9}$ & $\mathbf{1 0 0}$ & $\mathbf{4 9}$ & $\mathbf{1 0 0}$ & $\mathbf{4 9}$ & $\mathbf{1 0 0}$ & $\mathbf{4 9}$ & $\mathbf{1 0 0}$ \\
\hline
\end{tabular}

*: Doğru

Tablo incelendiğinde ön testte doğru cevap veren öğrenci sayısının iki grupta birbirine yakın olduğu, son testte deney grubunda daha fazla olduğu görülmektedir. Öğrenciler "Devrelerde pilin sayısı değişmiş.", “Piller. 1.'de 2 tane, 2. devrede 3 tane.” gerekçeleriyle pil sayısının bağımsız değişken olduğunu belirtmiştir. 
Öğretim öncesinde deney ve kontrol gruplarındaki 2 öğrenci "Pil sayısı değişince lamba parlaklığı değişecek" gerekçesiyle lamba parlaklığının bağımsız değişken olduğunu ifade etmiştir. $\mathrm{Bu}$ bulgu öğrencinin sebep ve sonuç arasında değişken türlerini belirleme bağlamında doğru bir ilişki kuramadığını ortaya koymaktadır. Öğretim sonunda bu kavram yanılgısı iki grupta da görülmemiştir.

Ön testte deney ve kontrol gruplarındaki birer öğrenci "bağlant1 kablosunun sağlam olmasını", ön ve son testte kontrol grubundaki 1 öğrenci "Anahtarın açı ya da kapalı olmasını değiştirebileceğimiz" ve "Anahtar lambanın parlaklığını etkilemediği için bağımsız değişkendir." gerekçeleriyle anahtarı bağımsız değişken olarak ifade etmiştir. Öğrencilerden biri anahtarın açık-kapalı olma konumunu istediği gibi değiştirebildiği için anahtarı bağımsız değişken olarak ifade ederken başka bir öğrenci ise lamba parlaklığı anahtara bağlı olmadığı için anahtarı bağımsız değişken olarak ifade etmiştir. Son testte deney ve kontrol gruplarındaki 2 öğrenci lamba sayısını bağımsız değişken olarak belirtmiştir. $\mathrm{Bu}$ durum öğrencilerin bağımsız değişken ile kontrol edilen değişkeni birbirine karıştırdıklarını ortaya koymaktadır.

Lamba sayısının sabit tutularak pil sayısının değiştirildiği bir deneyin kontrol edilen değişkeni (sabit tutulan değişken) için yüzde ve frekans değerleri Tablo 12'de verilmiştir. (Bkz: Ek. Soru 3C)

Tablo 12. Kontrol edilen değişken (sabit tutulan değişken)

\begin{tabular}{|c|c|c|c|c|c|c|c|c|}
\hline & \multicolumn{4}{|c|}{ ÖN TEST } & \multicolumn{4}{|c|}{ SON TEST } \\
\hline & \multicolumn{2}{|c|}{ DG } & \multicolumn{2}{|c|}{ KG } & \multicolumn{2}{|c|}{ DG } & \multicolumn{2}{|c|}{ KG } \\
\hline & f & $\%$ & f & $\%$ & f & $\%$ & f & $\%$ \\
\hline Lamba sayıs1* & 21 & 42,9 & 16 & 32,7 & 43 & 87,8 & 30 & 61,2 \\
\hline Pil sayısı & 1 & 2,0 & - & - & 1 & 2,0 & 4 & 8,2 \\
\hline Lamba parlaklığ & - & - & - & - & - & - & 3 & 6,1 \\
\hline Anahtar say1s1 & 9 & 18,4 & 11 & 22,4 & 1 & 2,0 & 4 & 8,2 \\
\hline Anahtar sayıs1 ve pil sayıs1 & - & - & 2 & 4,1 & - & - & - & - \\
\hline $\begin{array}{l}\text { Anahtar sayısı, bağlantı kablosunun } \\
\text { sağlamlığ1 }\end{array}$ & 1 & 2,0 & 2 & 4,1 & - & - & - & - \\
\hline Bağlantı kablosunun sağlamlığı & 1 & 2,0 & - & - & - & - & - & - \\
\hline Boş & 16 & 32,7 & 18 & 36,7 & 4 & 8,2 & 8 & 16,3 \\
\hline TOPLAM & 49 & 100 & 49 & 100 & 49 & 100 & 49 & 100 \\
\hline
\end{tabular}

*: Doğru 
Tablo incelendiğinde doğru cevap veren öğrenci sayısının deney grubunda az bir farkla kontrol grubuna nazaran daha fazla olduğu, son testte deney grubunda daha fazla olduğu görülmüştür. Öğrenciler "Lamba sayısını sabit tutmuş. Kontrol edilen değişkendir.”, "3 tane lamba. Eşit olduğu için lamba sayısı." gerekçeleriyle lamba sayısının kontrol edilen değişken olduğunu belirtmiştir.

Deney grubunda ön ve son testte 1 öğrenci pil sayısının kontrol edilen değişken olduğunu ifade etmiş, bu durum kontrol grubunda ön testte görülmemesine karşın son testte 4 öğrencide görülmüştür.

Öğretim sonunda kontrol grubundaki 3 öğrencinin lamba parlaklığının kontrol edilen değişken olduğunu ifade ettikleri görülmüştür. $\mathrm{Bu}$ bulgu öğrencilerin pil sayısındaki değişimin lamba parlaklığını etkilemeyeceğini düşündüklerini ortaya koymaktadır.

"İki devrede de 1 tane anahtar olduğu için" gerekçesiyle deney ve kontrol gruplarındaki bazı ögrenciler ön ve son testte anahtar sayısını kontrol edilen değişken olarak ifade etmişlerdir. Buradan öğrencilerin lamba parlaklığını etkileyen değişkenlerden ziyade daha çok devrede görsel olarak sayısı değişmeyen elemanlar üzerinde yoğunlaşarak cevap verdikleri anlaşılmaktadır. Ancak soruda verilen devrede lamba sayısı da her iki devrede aynı olmasına karşın öğrencilerin anahtar sayısına bağlı cevap vermeleri dikkat çekicidir.

Ön testte deney ve kontrol grubunda 2 öğrenci kontrol edilen değişken olarak bağlantı kablosunun sağlam olmasını ifade etmiştir. Bu bulgu öğrencilerin bağlantı kablosunun sağlam olmasını lamba parlaklığını etkileyen bir değişken olarak gördüklerini ve bağlantı kablosunun sağlam olmadığı durumda da lambanın yanacağına inandıklarını ortaya koymaktadır. Öğrenciler bağlantı kabloları sağlamken daha çok enerji geçeceği için lambanın daha parlak yanacağına, bağlantı kablolarında kesik ya da kopukluk olması durumunda daha az enerji geçeceği için lambanın parlaklığının azalacağına inanmaktadır.

\section{TARTIŞMA, SONUÇ VE ÖNERİLER}

Araştırma sonucunda lamba parlaklığını etkileyen değişkenler ile değişkenleri belirlemenin öğretiminde deney grubunda kullanılan analojinin etkili olduğu görülmüştür. Araştırmada deney grubunda kullanılan analoji ile gerçekleştirilen farklı uygulamalar öğrencilerin ilgi ve dikkatlerinin konuya çekilmesini sağlamada, dersi eğlenceli hale getirmede etkili olduğu için 
lamba parlaklığını etkileyen değişkenleri öğrenme ile değişken türlerini belirlemede deney grubunun kontrol grubuna göre daha başarılı olduğu düşünülmektedir. Alanyazında da ortaokul öğrencileri ile gerçekleştirilen çalışmalarda öğretim sürecinde analoji kullanımının akademik başarı (Demirci-Güler ve Yağbasan, 2010; Eskandar, Bayrami, Vahedi ve Ansar, 2013; Erökten ve Kahraman-Gökharman, 2013; Kobal, Şahin ve Kara, 2013; Şeker-Gökulu ve Geban, 2014) ile öğrenme (Blake, 2004; Çakır ve Azizoğlu, 2012; Çıray ve Erişti, 2014; Glynn ve Takahashi, 1998; ŞaşmazÖren, Ormanc1, Babacan, Çiçek ve Koparan, 2010) üzerinde olumlu etkileri olduğu saptanmıştır. Ayrıca analojilerin kavrama (Şenpolat, Seven ve Düzgün, 2005), kavramsal anlama (Blake, 2004; Wichaidit, Wongyounoi, Dechsri ve Chaivisuthangkura, 2011) üzerinde olumlu etkileri olduğu ortaya koyulmuştur.

Bununla birlikte ön ve son test sonuçlarında deney ve kontrol gruplarındaki bazı öğrencilerin lamba parlaklığı üzerinde herhangi bir etkisi olmayan lambanın pile yakınlığını, devrenin kapalı olmasını, bağlantı kablosunun sağlam olmasını, anahtarın açık/kapalı olmasını ve anahtar sayısını bağımsız, bağımlı ya da kontrol edilen değişken olarak ifade ettikleri görülmüştür. $\mathrm{Bu}$ durum bazı öğrencilerin lamba parlaklığını etkileyen değişkenlerle ilgili bilimsel açıdan doğru olmayan bilgilere sahip olduklarını ortaya koymaktadır.

Ön testte kontrol grubundaki bir öğrenci lambanın pile yakınlığını bağımlı, bağımsız ve kontrol edilen değişken olarak ifade etmiştir. $\mathrm{Bu}$ ögrenci lamba ile pil arasındaki mesafeyi lamba parlaklığını etkileyen bir değişken olarak kabul etmektedir. Bu araştırmada saptanmış olan kavram yanılgısı alanyazında "Deneysel Kural Modeli” olarak ifade edilmektedir. Bu modelde bir elektrik devresinde pile ya da güç kaynağına en yakın olan lamba diğerlerine göre daha parlak yanar. Lambanın güç kaynağına olan uzaklığı ile parlaklığı arasında ters orantı söz konusudur (Kaya ve GödekAltuk, 2010; Keser ve Başak, 2013; Türkoğuz ve Cin, 2013; Y1lmaz ve Huyugüzel-Çavaş, 2006). Öğrenci bir elektrik devresinde pile ya da güç kaynağına en yakın olan lambanın diğerlerine göre daha parlak yanacağını düşünmektedir. Bu düşünce alanyazında "Zayıflayan Akım Modeli” olarak ifade edilmektedir. Bu modelin temelinde "Güç kaynağının bir ucundan çıkan akım devredeki lamba tarafından kullanılır. Bu nedenle akım devrede zayıflayarak hareketine devam eder. Güç kaynağına geri dönen akım ilk duruma göre azalır" düşüncesi yer almaktadır (Borges ve Gilbert, 1999; Çepni ve Keleş, 2006; Osborne, 1981, 1983; Pardhan ve Bano, 2001; Yıldırım, Yalçın, Şensoy ve Akçay, 2008; Yılmaz ve Huyugüzel-Çavaş, 2006). Bu modelle ilgili olarak lambanın akımın tümünü kullandığ 
(Osborne, 1981, 1983; Pardhan ve Bano, 2001; Y1lmaz ve Huyugüzel-Çavaş, 2006), akımın bir kısmını kullandığı (Pardhan ve Bano, 2001) gibi düşünceler söz konusudur. Alanyazında "Zayıflayan Akım Modeli" olarak ifade edilen kavram yanılgısına ek olarak araştırmada "Zayıflayan EnerjiParlaklık Modeli” de saptanmıştır.

Kontrol grubundaki bir öğrenci son testte devrenin kapalı olmasını kontrol edilen değişken olarak ifade etmiştir. Bu ifade öğrencinin devrenin açık ya da kapalı olma durumunun lamba parlaklığı üzerinde etkili olduğunu düşündüğünü ortaya koymaktadır. Öğrencinin devrenin açık bir sistem olmasının parlaklığı etkileyecek bir değişken olduğunu düşünmesi açık devre sisteminde lambanın yanacağını düşündüğünü göstermesi bağlamında dikkat çekicidir.

Bazı öğrenciler bağlantı kablosunun sağlam olma durumunu bağımlı, bağımsız ya da kontrol edilen değişken olarak belirtmiştir. Bağlantı kablosunun sağlam olmasını kontrol edilen değişken olarak ifade eden ögrenciler görüşmelerde pilin pozitif kutbu ile lamba arasında yapılacak tek bir bağlantıda lambanın daha parlak yanacağını, negatif kutbu ile yapılacak tek bir bağlantıda ise parlaklığın azalacağını ifade etmişlerdir. Alanyazında da öğrencilerin pilin az elektrik oluşturan kutbunun negatif, çok elektrik oluşturan kutbunun pozitif olduğunu ifade ettikleri çalışmalar bulunmaktadır (Bakırcı, Subay, Midyatlı ve Ünsal, 2010; Çepni ve Keleş, 2006). Ayrıca bu araştırmadaki öğrenciler pilin pozitif ya da negatif kutbuna bağlanan lambanın yanacağını düşünmektedir. Alanyazında Tek Kutuplu Model olarak ifade edilen bu yanılg1 çoğu öğrenci tarafından doğru kabul edilmektedir (Çepni ve Keleş, 2006). Tek Kutuplu Modelde lamba ile pilin pozitif ya da negatif kutbu arasında yapılacak tek bir bağlantının (Bakırcı vd., 2010; Fleer, 1994; Keser ve Başak, 2013; Osborne, 1981; Yıldırım vd., 2008; Y1lmaz ve Huyugüzel-Çavaş, 2006; Yürümezoğlu ve Çökelez, 2010) ya da iki ayrı bağlantının (Yıldırım vd., 2008) lambanın yanması için yeterli olduğu düşünülmektedir. Bu modeli savunan öğrencilerin iletken telleri ya pilin aynı kutbuna ya da lambanın aynı noktasına bağladıkları (Yeşilyurt, 2006), lambalarla pil arasına tek bir kablo yerleştirdikleri (Çepni ve Keleş, 2006) ifade edilmektedir. Bu araştırmada ön testte deney ve kontrol gruplarında saptanan yanılgı son testte sadece kontrol grubunda görülmüştür.

Alanyazına ilave olarak araştırmanın dikkat çeken bir sonucu da değişken türlerini belirleme kazanımını ölçmeye yönelik sorulardan elde edilen verilerde öğrencilerin anahtarı "Devreden elektrik geçmesi anahtarın kapalı olmasına bağlıdır." gerekçesiyle bağımlı değişken; "Anahtar kapalı olunca elektrik geçer, açıkken geçmez.", "Anahtarın açık ya da kapalı 
olmasını değiştirebileceğimiz”, “Anahtar lambanın parlaklığını etkilemediği için bağımsız değişkendir." gerekçeleriyle bağımsız değişken ve "Anahtar. Çünkü devreleri kontrol ediyor.” gerekçeleriyle kontrol edilen değişken olarak ifade etmeleridir. Anahtarın kapalı ya da açık olması doğrudan lambanın 1 şı verme durumu ile ilgilidir. Anahtar lamba parlaklığını etkileyen bir değişken değildir. Öğrencilerdeki bu kavram yanılgısı son testte farklı sorular için deney grubunda 4 öğrencide, kontrol grubunda ise 18 öğrencide görülmüştür. Bu durum analoji kullanımının kavram yanılgılarını gidermede daha etkili olduğunu ortaya koymaktadır.

Ayrıca araştırmada bazı öğrencilerin bağımlı, bağımsız ve kontrol edilen değişken türlerini birbirlerinin yerine kullandıkları saptanmıştır. Benzer şekilde alanyazında da ortaokul öğrencilerinin (Anagün ve Yaşar, 2009; Ayas-Kör, 2006; Böyük vd., 2011; Durmaz ve Mutlu, 2012; Keser ve Başak, 2013; Ocak ve Tümer, 2014), 13-16 yaş aralığındaki öğrencilerin (Griffiths ve Thompson, 1993), lise 1. sınıf öğrencilerinin (Temiz ve Tan, 2009), 2. sınıfta (Bağcı-Kılıç vd., 2009), 3. sınıfta (Ateş, 2005; Ateş ve Bahar, 2002), son sınıfta öğrenim gören sınıf öğretmeni adaylarının (LaçinŞimşek, 2010), son sınıf fen bilgisi öğretmen adaylarının (Aydoğdu, 2012; Harman ve Çökelez, 2016), son sınıf biyoloji, sınıf, fen ve teknoloji öğretmen adaylarının (Saka, 2012) bağımlı, bağımsız ve kontrol edilen değişkenleri birbiri ile karıştırdıkları, değişkenleri belirleme becerilerinin yetersiz olduğu ortaya koyulmuştur. Alanyazında bağımsız, bağımlı ve kontrol edilen değişken kavramları öğrenmeyi güçleştirdiği için bağımsız değişken yerine değiştirilen değişken, bağımlı değişsen yerine cevap veren, ölçülen ya da gözlenen değişken ve kontrol edilen değişken yerine sabit tutulan değişken, sabitler, kontrol altına alınan ya da etkisi kontrol edilen değişken sözcüklerinin kullanılması gerektiği önerilmektedir (Ateş, 2005; Bağcı-Kılıç vd., 2009). Bu nedenle bu araştırmada da değişken türleri için hem öğretim hem de ölçme-değerlendirme aşamasında bağımlı değişken (cevap veren değişken), bağımsız değişken (değiştirilen değişken) ve kontrol edilen değişken (sabit tutulan değişken) kavramlarının her ikisi de kullanılmıştır. Ayrıca alınan uzman görüşlerinde mesleki deneyimleri 6-25 yıl arasında değişen 8 fen ve teknoloji öğretmeni değişken türlerine ait her iki kavrama da öğretimde ve sorularda yer verilmesinin gerekli ve önemli olduğunu belirtmiştir.

Araştırma sonucunda bazı öğrencilerin lamba parlaklığını etkileyen faktörler ile ilgili olarak çeşitli kavram yanılgılarına sahip oldukları görülmüştür. $\mathrm{Bu}$ nedenle öğretim sürecinde anahtar sayısının, anahtarın açık/kapalı olma durumunun, bağlantı kablosunun sağlam olmasının, lambanın pile yakınlığının, devrenin kapalı olmasının lamba parlaklığını 
etkileyen bir değişken olmadığının somut olarak gösterilmesinin gerekli ve önemli olduğu düşünülmektedir.

Bazı öğrencilerin ise değişkenleri belirleme ile ilgili olarak çeşitli kavram yanılgılarına sahip oldukları anlaşılmıştır. Bağımsız, bağımlı ve kontrol edilen değişken kavramlarını öğrenmek, akılda tutmak ve birbirleri ile karıştırmadan doğru bir şekilde ifade edebilmek güç olduğu için bağımsız değişken ile birlikte değiştirilen değişken, bağımlı değişken ile birlikte cevap veren, ölçülen ya da gözlenen değişken ve kontrol edilen değişken ile birlikte sabit tutulan değişken, sabitler, kontrol altına alınan ya da etkisi kontrol edilen değişken ifadeleri de kullanılmalıdır.

Kavram yanılgıları bağlamında ön ve son test sonuçları genel olarak incelendiğinde ön testte deney grubunda saptanan kavram yanılgılarının son testte azaldığı ya da tamamen giderildiği saptanmıştır. Kontrol grubunda ise ön testte saptanan kavram yanılgılarının son testte aynı kaldığı ya da artış gösterdiği görülmüştür. Bu sonuç analoji kullanımının kavram yanılgılarının giderilmesi üzerinde de etkili olduğunu ortaya koymaktadır.

Bireylerin günlük yaşamlarında karşılaştıkları bir problemi çözerken bilimsel süreç becerilerinden yararlanarak problemleri kuracakları hipotezleri test ederek çözebilecekleri düşünüldüğünde hipotez test etmede değişkenleri belirleme ve kontrol edebilme becerilerinin kazanılması son derece önemlidir. Öğrencilerin kendilerine verilen bir durumla ilgili bağıml, bağımsız ve kontrol edilen değişkenleri belirleyebilmeleri ve bir sonraki adımda da sonuca ulaşabilmeleri için değişkenleri kontrol edebilmeleri gereklidir. Bu nedenle değişkenleri belirlemenin öğretiminde daha ilgi çekici ve eğlenceli etkinliklerle ders işlenmeli, dikkat çekici materyaller kullanılarak somut uygulamalar yapılmalıdır.

\section{KAYNAKÇA}

Akdeniz, A. R., 2011. Problem Çözme, Bilimsel Süreç ve Proje Yönetiminin Fen Eğitiminde Kullanımı, (Ed.), Salih Çepni, Kuramdan Uygulamaya Fen ve Teknoloji Öğretimi, Ankara, Pegem Akademi. (ss. 154-179).

Anagün, S. Ş. ve Yaşar, Ş., 2009. İlköğretim beşinci sınıf fen ve teknoloji dersinde bilimsel süreç becerilerinin geliştirilmesi. Illkögretim Online, 8(3), 843-865.

Ateş, S., 2005. Öğretmen adaylarının değişkenleri belirleme ve kontrol etme yeteneklerinin geliştirilmesi. Gazi Üniversitesi Gazi Ĕ̈itim Fakültesi Dergisi, 25(1), 21-39.

Ateş, S. ve Bahar, M., 2002. Araştırmacı fen öğretimi yaklaşımıyla sınıf öğretmenliği 3. sınıf öğrencilerinin bilimsel yöntem yeteneklerinin geliştirilmesi. V. Ulusal Fen Bilimleri ve Matematik Ĕgitimi Kongresi, 16-18 Eylül 2002, ODTÜ, Ankara. 
Ayas-Kör, S., 2006. İlköğretim 5. Sınıf Öğrencilerinde "Yaşamımızdaki Elektrik" Ünitesinde Görülen Kavram Yanılgılarının Giderilmesinde Bütünleştirici Öğrenme Kuramına Dayalı Geliştirilen Materyallerin Etkisi. Yayınlanmamış Yüksek Lisans Tezi, Karadeniz Teknik Üniversitesi Fen Bilimleri Enstitüsü, Trabzon.

Aydoğdu, B., 2012. Fen bilgisi öğretmen adaylarının hipotez kurma ile değişkenleri belirleme ve kontrol etme becerilerinin incelenmesi. X. Ulusal Fen Bilimleri ve Matematik Eğitimi Kongresi, 27-30 Haziran 2012, Niğde.

Bağcı-Kılıç, G., Yardımc1, E. ve Metin, D., 2009. Fen öğretiminde değişkenler nasıl adlandırılabilir?. Abant İzzet Baysal Üniversitesi Eğitim Fakültesi Dergisi, 9(2), 1326.

Bakırc1, H., Subay, S., Midyatlı, F. ve Ünsal, N., 2010. İlköğretim ikinci kademe öğrencilerinin bazı fen kavramlarıyla ilgili düşüncelerinin sınıf seviyesine göre incelenmesi. Abant İzzet Baysal Üniversitesi Eğitim Fakültesi Dergisi, 10(1), 31-48.

Blake, A., 2004. Helping young children to see what is relevant and why: Supporting cognitive change in earth science using analogy. International Journal of Science Education, 26(15), 1855-1873.

Borges, A. T. and Gilbert, J. K., 1999. Mental models of electricity. International Journal of Science Education, 21(1), 95-117.

Bozkurt, O. ve Olgun, Ö. S., 2005. Fen ve Teknoloji Eğitiminde Bilimsel Süreç Becerileri, (Ed.), Mustafa Aydoğdu ve Teoman Kesercioğlu, Illköğretimde Fen ve Teknoloji Ögretimi, Ankara, Anı Yayınc1lık. (ss. 56-70).

Böyük, U., Tanık, N. ve Saraçoğlu, S., 2011. İlköğretim ikinci kademe öğrencilerinin bilimsel süreç beceri düzeylerinin çeşitli değişkenler açısından incelenmesi. TÜBAV Bilim, 4(1), 20-30.

Çakır, C. ve Azizoğlu, N., 2012. Maddeyi oluşturan tanecikler konusunun analojilerle destekli öğretiminin öğrencilerin akademik başarısına etkisi. $I V$. Uluslararası Türkiye Eğitim Araştırmaları Kongresi, 4-7 Mayıs 2012, İstanbul.

Çepni, S. and Keleş, E., 2006. Turkish students' conceptions about the simple electric circuits. International Journal of Science and Mathematics Education, 4(2), 269-291.

Çıray, F. ve Erişti, B., 2014. Disiplinler arası analoji tabanlı öğretimin farklı düzeylerde akademik başarılı ilköğretim öğrencilerinin fen ve teknoloji dersi öğrenme düzeyleri üzerindeki etkisi. İlköğretim Online, 13(3), 1049-1064.

Demirci-Güler, M. P. ve Yağbasan, R., 2010. Fen ve teknoloji dersinde analoji kullanımının öğrencilerin başarı, tutum ve bilgilerinin kalıcılığına etkisi. International Science and Technology Conference, 27-29 October 2010, Turkish Republic of Northern Cyprus.

Duit, R., 1991. On the role of analogies and metaphors in learning science. Science Education, 75(6), 649-672.

Durmaz, H. ve Mutlu, S., 2012. 7. sınıf öğrencilerinin bilimsel süreç becerilerini geliştirmeye yönelik bir çalışma örneği. Necatibey Eğitim Fakültesi Elektronik Fen ve Matematik Ĕgitimi Dergisi (EFMED), 6(1), 124-150.

Ekici, E., Ekici, F. ve Aydın, F., 2007. Fen bilgisi derslerinde benzeşimlerin (analoji) kullanılabilirliğine ilişkin öğretmen adaylarının görüşleri ve örnekleri. Ahi Evran Üniversitesi Kırşehir Ĕgitim Fakültesi Dergisi (KEFAD), 8(1), 95-113. 
Eskandar, F-A., Bayrami, M., Vahedi, S. and Ansar, V. A. A., 2013. The effect of instructional analogies in interaction with logical thinking ability on achievement and attitude towards chemistry. Chemistry Education: Research and Practice, 14, 566-575.

Erökten, S. and Kahraman-Gökharman, H., 2013. The effect of analogy method on student achievement in the unit "the structure and properties of matter" çivril sample. World Applied Sciences Journal, 23(6), 744-750.

Fleer, M., 1994. Determining children's understanding of electricity. The Journal of Educational Research, 87(4), 248-253.

Gentner, D., 1983. Structure-mapping: A theoretical framework for analogy. Cognitive Science, 7(2), 155-170.

Glynn, S. M. and Takahashi, T., 1998. Learning from analogy-enhanced science text. Journal of Research in Science Teaching, 35(10), 1129-1149.

Griffiths, A. K. and Thompson, J., 1993. Secondary school students' understandings of scientific process: An interview study. Research in Science \& Technological Education, 11(1), 15-26.

Harman, G. and Çökelez, A., 2015. Teaching the effect of variables on the brightness of a light bulb in a simple electrical circuit using a pneumatic system model (PSM). International Journal of Physical Sciences, 10(6), 215-221.

Harman, G. ve Çökelez, A., 2016. Fen bilgisi öğretmen adaylarının bilimsel süreç becerilerini anlama düzeylerinin belirlenmesi: Elektromıknatısın çekim gücü örneği. International Conference on Education in Mathematics, Science \& Technology (ICEMST 2016), 19-22 Mayıs 2016, Bodrum.

Kaya, V. H. ve Gödek-Altuk, Y., 2010. İlköğretim öğrencilerinin basit elektrik devresi konusu ile ilgili kavram yanılgıları. I. Ulusal Ĕ̆itim Programları ve Öğretim Kongresi, 1315 Mayıs 2010, Balıkesir.

Keser, Ö. F. ve Başak, M. H., 2013. Yaşamımızdaki elektrik ünitesine yönelik öğrenci kazanım düzeylerinin incelenmesi. Türk Fen Eğitimi Dergisi, 10(2), 116-137.

Kesercioğlu, T., Yılmaz, H., Huyugüzel-Çavaş, P. ve Çavaş, B., 2004. İlköğretim fen bilgisi öğretiminde analojilerin kullanımı: Örnek uygulamalar. Ege Eğitim Dergisi, 5, 3544.

Kobal, S., Şahin, A. ve Kara, İ., 2013. Fen ve teknoloji dersinde analojilere dayalı öğretimin öğrencilerin başarıları ve hatırda tutma düzeyi üzerindeki etkisi. Buca Eğitim Fakültesi Dergisi, 36, 46-61.

Laçin-Şimşek, C., 2010. Sınıf öğretmeni adaylarının fen ve teknoloji ders kitaplarındaki deneyleri bilimsel süreç becerileri açısından analiz edebilme yeterlilikleri. İlkögretim Online, 9(2), 433-445.

Ocak, İ. ve Tümer, H., 2014. İlköğretim 5. sınıf öğrencilerinin bilimsel süreç becerilerine sahip olma düzeyleri (Afyonkarahisar İli Örneği). Afyon Kocatepe Üniversitesi Fen ve Mühendislik Bilimleri Dergisi, 14, 1-21.

Osborne, R., 1981. Children's ideas about electric circuits. New Zealand Science Teacher, 29, 12-19.

Osborne, R., 1983. Towards modifying children's ideas about electric current. Research in Science and Technological Education, 1(1), 73-82. 
Pardhan, H. and Bano, Y., 2001. Science teachers' alternate conceptions about direct-currents. International Journal of Science Education, 23(3), 301-318.

Saka, A., 2012. Öğretmen adaylarının nedensel süreç becerileri açısından değerlendirilmesi. X. Ulusal Fen Bilimleri ve Matematik Eğitimi Kongresi, 27-30 Haziran 2012, Niğde.

Şaşmaz-Ören, F., Ormancı, Ü., Babacan, T., Çiçek, T. ve Koparan, S., 2010. Analoji ve araştırma temelli öğrenme yaklaşımına dayalı rehber materyal uygulaması ile buna yönelik öğrenci görüşleri. Batı Anadolu Ĕ̆itim Bilimleri Dergisi, 1(1), 33-53.

Şeker-Gökulu, A. and Geban, Ö., 2014. Facilitating conceptual change in atom, molecule, ion and matter concepts. Dicle Üniversitesi Ziya Gökalp Eğitim Fakültesi Dergisi, 23, 304-322.

Şenpolat, Y., Seven, S. ve Düzgün, B., 2005. Fen bilgisi öğretiminde analoji kullanımının öğrenci başarısına ve derse yönelik tutumlarına etkisinin araştırılması. Çukurova Üniversitesi Eğitim Fakültesi Dergisi, 31(2), 94-101.

Temiz, B. K. ve Tan, M., 2009. Lise 1. sınıf öğrencilerinin değişkenleri belirleme ve hipotez kurma becerileri. Kastamonu Eğitim Dergisi, 17(1), 195-202.

Türkoğuz, S. ve Cin, M., 2013. Argümantasyona dayalı kavram karikatürü etkinliklerinin öğrencilerin kavramsal anlama düzeylerine etkisi. Buca Eğitim Fakültesi Dergisi, 35, 155-173.

Wichaidit, S., Wongyounoi, S., Dechsri, P. and Chaivisuthangkura, P., 2011. Using analogy and model to enhance conceptual change in thai middle school students. US-China Education Review, 8(3), 333-338.

Yeşilyurt, M., 2006. İlköğretim ve lise öğrencilerinin elektrik kavramı ile ilgili düşünceleri. Elektronik Sosyal Bilimler Dergisi, 5(17), 41-59.

Yıldırım, H. İ., Yalçın, N., Şensoy, Ö. ve Akçay, S., 2008. İlköğretim 6., 7. ve 8. sınıf öğrencilerinin elektrik akımı konusunda sahip oldukları kavram yanılgıları. Kastamonu Ĕgitim Dergisi, 16(1), 67-82.

Yıldırım, A. ve Şimşek, H., 2011. Sosyal bilimlerde nitel araştırma yöntemleri (8. Baskı). Ankara: Seçkin Yayıncılık.

Yılmaz, H. ve Huyugüzel-Çavaş, P., 2006. 4-E öğrenme döngüsü yönteminin öğrencilerin elektrik konusunu anlamalarına olan etkisi. Türk Fen Ĕgitimi Dergisi, 3(1), 2-18.

Yürümezoğlu, K. ve Çökelez, A., 2010. Akım geçiren basit bir elektrik devresinde neler olduğu konusunda öğrenci görüşleri. Türk Fen Eğitimi Dergisi, 7(3), 147-166.

\section{EXTENDED ABSTRACT}

This study investigated the effect of the using analogy on the teaching of types of variables affecting on the brightness of a bulb, identifying variables, learning and elimination misconceptions. The study was conducted with the participation of 98 fifth grade students. 49 students were in the experimental group and 49 students were in the control group. The study was based on an unmatched control group pretest and posttest method. Individual interviews were conducted with five students in the experimental and five students in the control groups.

The researcher participated in the lesson of experimental and control groups as an observer. The teacher was informed about application before lesson by the 
researcher. Teaching was implemented for two lesson hours. Analogy that was called Pneumatic System Model (PSM) was used in the experimental group. Students were asked to establish an analogical relationship between the PSM and the Simple Electric Circuit (SEC). Then the teacher explained the analogical relationship between PSM and SEC. The analogical relationship between air pump and battery, plastic balloon and bulb, plastic transparent hose and connection cable, valve and switch were explained to students by the teacher. The concepts of dependent, independent and controlled variables were explained to fifth grade students by the teacher. Students were asked to identify the variables in PSM 1-2-3. They were asked to express dependent, independent, and controlled variables by making the comparison between PSM 1-PSM 2 and PSM 2-PSM 3. Students were asked to identify the variables in SEC 1-2-3. They were asked to express dependent, independent, and controlled variables by making the comparison between SEC 1SEC 2 and SEC 2-SEC 3. After explanations were made by the students, the teacher expressed dependent, independent and controlled variables in PSM 1-2-3 and SEC 1-2-3. Analogy was not used in the control group. The concepts of dependent, independent and controlled variables were explained to students in the control group. Students were asked to identify the variables in SEC 1-2-3. They were asked to express dependent, independent, and controlled variables by making the comparison between SEC 1-SEC 2 and SEC 2-SEC 3. After explanations were made by the students, the teacher expressed dependent, independent and controlled variables in SEC 1-2-3.

In order to prepare the data collection tool, the curriculum was examined, national and international literature was investigated, expert opinion was taken and pilot application was made. A data collection tool containing of 3 cases was prepared. The students were asked a total of 9 questions, including 3 questions for each case. Students were asked to express dependent, independent and controlled variables in the situations that were given to them.

Data were analyzed using content analysis. Frequency and percentage values were calculated, tables were prepared and tables were interpreted. In addition to, direct citation from student answers were presented.

As a result of the research, it was found that analogy was effective on the teaching of types of variables affecting on the brightness of a bulb and identifying variables. Other studies in the literature also reported that analogy is effective in teaching. As a result of this research, it was understood that some students had misconceptions about the variables affecting on the brightness of a bulb. According the pre-test and post-test results, some students in the experimental and control groups expressed factors affecting the brightness of the bulb such as the distance between battery and bulb, circuit must be a close system, the strength of the connection cable, switch is open or close, the number of switch. Some students had misconceptions about identifying variables. It was determined that some students used dependent, independent and controlled variable types instead of each other. It was seen that these misconceptions were largely eliminated in the experimental 
group. This result demonstrated that analogy was effective on the elimination of misconceptions. Other studies in the literature also reported that analogy was effective on the elimination of misconceptions.

It is difficult to learn, keep in mind and express correctly without mixing with each other these concepts of independent, dependent and controlled variables. For this reason, independent variables and modified variable; dependent variable and responding variable, measured or observed variable; controlled variable and fixed variable, constants, controlled or effect controlled variable concepts should be expressed together. Individuals solve a problem that they encounter in their daily life by using scientific process skills. Individuals solve problems by establishing and testing hypothesis. Identifying and controlling variables that is one of the scientific process skills is extremely important, for hypothesis is tested. For this reason, it is important that students can identify and control dependent, independent, and controlled variables. Therefore intriguing and fun activities should be used in the teaching of determining variables and concrete applications should be made using remarkable materials.

EK: Veri Toplama Arac1

Soru 1: Umut basit bir elektrik devresinde lamba sayısının lamba parlaklığına olan etkisini deney yaparak araştırmak istiyor.

Soru 1A: Umut'un yapacağı deneydeki bağımlı değişkeni (cevap veren değişken) yazınız. Cevabınızın nedenini açıklayınız.

Soru 1B: Umut'un yapacağı deneydeki bağımsız değişkeni (değiştirilen değişken) yazınız. Cevabınızın nedenini açıklayınız.

Soru 1C: Umut'un yapacağı deneydeki kontrol edilen değişkeni (sabit tutulan değişken) yazınız. Cevabınızın nedenini açıklayınız.

\section{Soru 2}

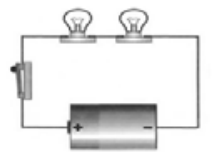

1.devre

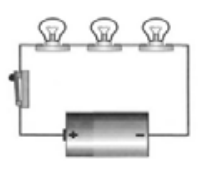

2.devre

Sevilay yapacağı deney için kurduğu devreyi yukarıda verilen şekilde olduğu gibi 1. devreden 2. devreye çevirirse,

Soru 2A: Sevilay'ın yaptığı deneydeki bağımlı değişkeni (cevap veren değişken) yazınız. Cevabınızın nedenini açıklayınız. 
Soru 2B: Sevilay’ın yaptığı deneydeki bağımsız değişkeni (değiştirilen değişken) yazınız. Cevabınızın nedenini açıklayınız.

Soru 2C: Sevilay'ın yaptığı deneydeki kontrol edilen değişkeni (sabit tutulan değişken) yazınız. Cevabınızın nedenini açıklayınız.

\section{Soru 3}

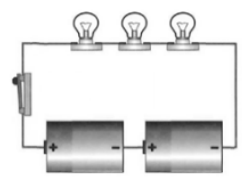

1.devre

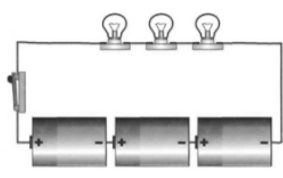

2.devre

Ela yapacağı deney için kurduğu devreyi yukarıda verilen şekilde olduğu gibi 1. devreden 2. devreye çevirirse,

Soru 3A: Ela'nın yaptığı deneydeki bağımlı değişkeni (cevap veren değişken) yazınız. Cevabınızın nedenini açıklayınız.

Soru 3B: Ela'nın yaptığı deneydeki bağımsız değişkeni (değiştirilen değişken) yazınız. Cevabınızın nedenini açıklayınız.

Soru 3C: Ela'nın yaptığı deneydeki kontrol edilen değişkeni (sabit tutulan değişken) yazınız. Cevabınızın nedenini açıklayınız. 
